\title{
Do Labour Market Conditions Affect Gift Exchange? Some Experimental Evidence
}

\author{
Jordi Brandts and Gary Charness
}

July 8,2003

\begin{abstract}
We study how two dimensions of market conditions affect behavior in experimental gift-exchange markets with repeated interaction. First, we consider the impact of competitive imbalance, by varying whether there is an excess supply of firms or an excess supply of workers in the market. Second, we impose a minimum wage in the market with an excess supply of workers, and study the overall effect on wages and productivity. Perhaps surprisingly, the state of competition does not appear to have strong effects in our data; however, there is some evidence of lower productivity when a minimum wage is imposed.
\end{abstract}

Keywords: Experiments, Labour Market, Minimum Wage, Social Preferences, Reciprocity

JEL Classification Numbers: C90, D63, J30

Contact: Jordi Brandts, Instituto de Análisis Económico (CSIC), Barcelona (Brandts@uab.es); Gary Charness, Dept. of Economics, UCSB (charness@econ.ucsb.edu). This paper is part of the EU-TMR Research Network ENDEAR (FMRX-CT98-0238), and this research was undertaken while Charness was affiliated with Universitat Pompeu Fabra, Barcelona. The authors thank Isabel Busom, David Cooper, David de Meza, Ernst Fehr, Guillaume Fréchette, Philippe Polomé, Jim Warnicke, Shmuel Zamir, and two anonymous referees for helpful comments, Brit Grosskopf and Carles Solà for their help in running the experiments and David Rodríguez for very able research assistance. Financial support from the Spanish DGCICYT (PB93-0679, PB94-0663-C03-01 and PB98-0465) is gratefully acknowledged. Charness also gratefully acknowledges support from the MacArthur Foundation and the Russell Sage Foundation. 


\section{INTRODUCTION}

Gift exchange markets, in the Akerlof (1982) sense, have been employed as experimental representations of labor markets with variable effort and of goods markets with variable quality. Issues related to cooperative behavior play a prominent role in this form of market. The experimental analysis of these situations, first studied by Fehr, Kirchsteiger and Riedl (1993), has shown that behavior usually deviates substantially from simple own-payoff maximization. Yet some of the motivational underpinnings of the remarkable behavior observed in these experiments are still quite unclear. In particular, there has been no previous study on whether and how gift exchange is affected by the direction of the competitive pressures that are present in a market environment. Similarly, there is no evidence on whether gift-exchange is affected by the existence of a minimum wage, an institution that is present in most market economies. Our aim in this paper is to study the effects of these features of market conditions on the patterns of gift exchange.

One can describe the basic sequence of events in a typical experimental gift-exchange market in the following manner: There are two types of agents (firms and workers) participating in the market, and the number of firms may or may not be equal to the number of workers. First, firms make wage offers - gifts - in a one-sided auction and workers have the opportunity of accepting them; in the standard case, workers cannot make counter-offers. ${ }^{1}$ After a worker has accepted a firm's offer, the two parties become matched and the wage cannot be changed. A firm can only be matched with one worker and vice versa. Workers then choose effort levels and are free to select any of the feasible levels, including one with zero cost. They decide the extent to 
which they return possible gifts. Holding effort constant, higher wages yield lower monetary payoffs for firms and higher ones for workers; higher effort levels have the reverse effect on payoffs, holding wages constant.

The standard game-theoretic prediction is that workers will invariably choose the lowest possible effort level, since this choice is dominant in a pecuniary sense; in anticipation of this, firms will only make the lowest possible wage offer. However, numerous studies of this game, for example Fehr, Gächter and Kirchsteiger (1997), Fehr, Kirchsteiger and Riedl (1998) and Hannan, Kagel and Moser (2002), have established a highly significant positive relationship between the wage assigned and the effort level chosen. The investment game of Berg, Dickhaut \& McCabe (1995) is a related sequential two-player game, in which the first-mover's pass is tripled and the responder's pass is not augmented. Ninety-two percent of all senders sent a positive amount of money, and $80 \%$ of all responders who were sent money returned a positive amount. ${ }^{2}$ Another related sequential prisoner's dilemma study is Clark and Sefton (2001). Here they use a series of $2 \times 2$ games. Responders choose to cooperate much more frequently after first-mover cooperation than after first-mover non-cooperation.

Results from experimental gift-exchange and related games have been very influential in establishing the relevance of social preferences in economic environments. However, to date there is no clear agreement on the precise motivational forces behind the observed behavior. In particular, it remains to be established how gift-exchange is affected by the degree to which it is embedded in a market environment. Perhaps a worker makes a costly effort choice because of his

\footnotetext{
${ }^{1}$ Fehr and Falk (1999) study the case where workers can make counter-offers.

2 These figures combine the "no history" and "social history" treatments.
} 
perception of the kindness of the wage offer. In this case, changes in market conditions may lead to changes in wage offers and in the way that workers view a given wage. Alternatively, pure outcome-based models (e.g., Fehr and Schmidt 1999; Bolton and Ockenfels 2000) have argued that costly effort provision is not a response to kindness, but instead it is a form of generosity that reflects concerns about the distribution of payoffs. To the extent that costly effort stems from purely distributive motivations, choices should not depend on market conditions.

We first study how behavior is affected by the state of competition, by which we mean the relationship between the number of firms and the number of workers. In experimental gift exchange markets there may be more workers than firms or the other way around, and this relation determines whether labor is in excess supply or excess demand. We are interested in the psychological, not in the strategic, impact of varying the direction of the competitive pressure. We believe that the psychology of competition is an important socio-economic issue. If the state of competition were to have a significant effect on behavior, due to some form of interdependence of motivations, this would affect the very basis of how economists think about markets, since it would imply that a specific feature of the economic environment interacts with people's preferences in these markets.

We also examine the effect of imposing a minimum wage on the behavior of firms and workers. A minimum-wage requirement is a prominent feature in contemporary labor markets, and so the effect of a minimum wage on behavior and productivity is an issue of considerable economic importance. At the same time, looking at its impact may help identify the precise motivation for gift-exchange. If the existence of a minimum wage were to affect gift-exchange at all, that would be another instance of interaction between preferences and environment; if, in 
addition, the minimum wage led to lower gift-exchange and income levels, this would be a new type of negative effect of this labor market restriction, beyond the negative employment effect associated with more standard analysis.

The unifying feature for both of these issues is the question of whether worker behavior is sensitive not only to the wage offer, but also to the 'background' or the circumstances surrounding the situations in which gift exchange takes place. For example, if there are more workers than jobs, one might not need to offer as high a wage as when there are more jobs than workers. Thus, a certain wage might appear to be more generous when the competitive balance favors the firms, since workers may attribute the wage to competitive pressures. Similarly, if we impose a minimum wage in a market where the firms hold the power, we might expect that a particular wage offer may seem less generous, since it is plausibly evaluated in relation to the lowest possible one.

The focus of our study is very much related to the more general theme that preferences depend not only on the outcomes that follow from certain choices, but also on information concerning the process leading to these outcomes. Information pertaining to the process - and not to the outcome - may matter because it offers inferences about the intentions or disposition behind the actions of others. The state of competition and the presence of a minimum wage are, in our view, quite relevant to the process by which market allocations are determined.

We believe that our paper contributes to the identification of the precise determinants of behavior in gift-exchange games. To make progress in this direction, it is necessary to rigorously study gift-exchange behavior from a variety of different angles. Note that it would be difficult to carry out this kind of analysis on the basis of field data alone, since in natural environments it 
would be unusual to find data with the desired variations in the non-outcome information. In contrast, experiments make it possible to generate this kind of evidence in a systematic manner.

Our results suggest, perhaps surprisingly, that gift-exchange behavior is not greatly affected by certain changes in market conditions. We do not find major differences in responsiveness to wages in our comparisons, although we do find some modest effects across some of the treatments. In particular, an imposed minimum wage seems to lower effort provision at all wages, and also decreases the likelihood that a high wage is paid. In our final section we present a discussion of the manner in which our results mesh with other findings concerning the effects of non-outcome information on choice.

\section{BACKGROUND}

Roth, Prasnikar, Okuno-Fujiwara \& Zamir (1991) demonstrate that results are very different for an ultimatum game with one-to-one matching and a "market game" in which a single agent on one side can agree to a proposal from any of nine agents on the other side. This kind of difference in behavior can easily be explained in terms of purely distributional preferences (see Bolton and Ockenfels, 2000). Our first focus is on the more emotional links between market imbalance and behavior.

In our markets, contracts can be considered to be incomplete, in the sense that workers make their choices after wages have been fixed and there is no monitoring or sanctioning of any kind. ${ }^{3}$ In previous gift-exchange experiments the number of workers was about $1 / 3$ to $1 / 2$ higher

\footnotetext{
${ }^{3}$ Brown, Falk, and Fehr (2002) find that contractual incompleteness "causes fundamental changes in the nature of market interactions" in a repeated-interaction environment. When there are excess workers and complete contracts
} 
than the number of firms; no previous study has considered the case whether there are more jobs than there are workers. However, in times of economic boom or when a task is highly specialized, such conditions are not uncommon; Silicon Valley experienced a chronic shortage of high-tech workers in the late 1990's. In such a context, we conjecture that workers may perceive a higher wage to be inspired by 'pure gift-giving' (when there is an excess of workers) or 'giftgiving under competitive pressures' (when there is an excess of firms).

Bowles (1998) presents a detailed survey of the literature on the different ways in which institutions may affect values, tastes and personalities. One of the several issues he discusses is closely related to the effect of market imbalance on the motivation of market participants. He states: “...or to take another example, there are significant differences in the personality effects on participants in markets which clear in equilibrium and those which do not, and in those markets which do not clear, for people on the short side of the market (whose advantageous positions may allow them to make take it or leave it offers) and those on the long side of the market, some of whom are simply excluded from the exchange process, while others fear losing the transactions they have secured."4

Minimum wages, our second focus, were instituted in part as a response to the 'sweatshop' abuses of the $19^{\text {th }}$ century and earlier. The essential idea relates to equitable income distribution, in principle enabling even the poorest classes to earn a 'decent' living. The effect of a minimum wage on employment has been the subject of numerous studies based on field data.

(external enforcement of effort), firms hold workers to little more than their reservation payoffs; in contrast, workers earn generous rents in a market with incomplete contracts and an excess supply of workers.

${ }^{4}$ For a more general discussion of the effects of participation in markets on preferences see also Lane (1991). 
Card and Krueger (1995) contains an overview of this research, which deals with whether the minimum wage has a positive or negative effect on employment.

The effect of a minimum wage on market behavior and productivity has not been directly studied in the laboratory in a context of incomplete contracts and market competition. To the best of our knowledge, Falk, Fehr, and Zehnder (2002) is the only other experimental study that specifically considers minimum wages in labor markets. They find that having a minimum wage that is higher than the usual wage paid leads to more employment, in that workers are less likely to reject higher wages. However, their study is quite different since it does not consider the case of discretionary effort for an employed worker. In addition, since only one wage offer is made known to each worker in each period, this design does not feature public market interaction.

Information about market conditions may be useful for inferring the intentions of others, as it pertains to the opportunities that others have in the market. In a review of the connections between psychology and economics, Rabin (1998) discusses the relationship between opportunities and the attribution of intentions. He states that: "When motivated by reciprocal altruism, for instance, people differentiate between those who take a generous action by choice and those who are forced to do so." Whether people are 'forced to be generous' may depend on the situation in which they find themselves. ${ }^{5}$ In particular, a minimum-wage régime may be seen as forcing employers to be generous beyond what they otherwise would be.

\footnotetext{
${ }^{5}$ Charness (forthcoming) considers the effect of attribution for a wage in a gift-exchange labor market, comparing responses to firm-determined wages to responses to wages determined either by a draw from a bingo cage or by a third party. While the attribution of volition has a significant effect on behavior when wages are relatively low, effort choices do not vary across treatments at high wages. Blount (1995) and Offerman (2002) also study attribution (in non-gift-exchange games) and find evidence that the process leading to the available alternatives affects responder behavior
} 
Sen (1997) provides a general discussion of the influence that the act of choice may have on behavior and suggests that relevant factors can be classified as either chooser dependence or menu dependence. ${ }^{6}$ Differences in characteristics of decision-makers reflect chooser dependence, while the possible impact of foregone opportunities (or of social information) relates to menu dependence. For example, studies of the effect of causal attribution on behavior concern chooser dependence, while studies of the effect of foregone opportunities (alternative courses of action that other players could have taken but didn't) concern menu dependence. In the latter category, Brandts and Solà (2001), Falk, Fehr, and Fischbacher (forthcoming), and Charness and Rabin (2002) find definite evidence that the likelihood of an offer being rejected is affected by the options that were not exercised. ${ }^{7}$

In a broad sense, our study pertains to Sen's menu dependence - a worker may judge a given wage offer in relation to a firm's set of options. However, it also speaks to the predictions of formal models of interdependent preferences. These all predict a positive relation between wages and effort levels, although for different reasons. Bolton and Ockenfels (2000) and Fehr and Schmidt (1999) propose models in which individual motivation is increasing in one's financial reward and decreasing in disparities among payoffs, but does not depend on other circumstances. In contrast, Rabin (1993) and Dufwenberg and Kirchsteiger (forthcoming) present models of kindness-based reciprocity, in which beliefs about the kindness of another player's action can

\footnotetext{
${ }^{6}$ Sen's classification is a useful organizing tool, although it may not easily cover all ways in which non-outcome information may affect behavior.

${ }^{7}$ On the other hand, Bolton, Brandts and Ockenfels (2001) present some results from simple sequential dilemma games and find that foregone opportunities do not affect behavior significantly.
} 
affect behavior. A higher wage induces a greater effort response due to positive reciprocity for the firm's perceived intentional kindness. ${ }^{8}$

These classes of models differ in their predictions concerning the effect of the marketcondition changes we study. The purely outcome-based models predict higher effort for higher wages, due to the larger interim payoff disparity between the firm and the worker when a higher wage is offered. However, they also predict that the patterns of behavior will not differ across our treatments. In contrast, the kindness-based reciprocity models as formulated predict a definite difference in behavior when a minimum wage is introduced, and a plausible difference as well according to the state of competition.

One such model, developed for sequential games such as ours, is that of Dufwenberg and Kirchsteiger (forthcoming). As in the Rabin (1993) model, the degree of perceived kindness of an action is determined with respect to a range of feasible choices. Intuitively, imposing a minimum wage shrinks this range, so that wage offers close to the minimum wage are less kind than the same wage offers when the feasible range includes the lowest wages. On the other hand, the highest wage in any non-degenerate range is always considered completely kind in this model.

With respect to imbalanced markets, if workers feel that competitive pressures cause firms to increase wages when there are more jobs than workers, the lowest 'feasible' wage would be higher, shrinking the suitable or applicable wage range. Since an intermediate wage would then

\footnotetext{
${ }^{8}$ The Charness and Rabin (2002) model does not consider kindness or positive reciprocity. One is instead motivated to some degree by the desire to do what is "socially appropriate' - to sacrifice money to promote the aggregate social utility, taking into account the total payoff and the lowest payoff for anyone in the group. This model predicts lower effort for lower wages, as each worker withdraws his (heterogeneous) concern (and thus his willingness to sacrifice) for a firm that offers less than the 'socially-appropriate' wage. However, there is no obvious manner in which the presumably fairly high (for social-efficiency reasons) appropriate wage will differ across treatments, so that no difference in behavior is predicted across treatments.
} 
be considered less kind when the supply of labor is scarce (with top wages equally kind in either case), this would lead to the same qualitative prediction as with a minimum wage. ${ }^{9}$

\section{EXPERIMENTAL DESIGN, PROCEDURES \& HYPOTHESES}

We conducted a total of 16 experimental sessions in Barcelona, involving a total of 306 participants. We used a multi-period design in 12 of these sessions, as is standard in experimental gift-exchange games, with 10 periods in each session; in the other four sessions we studied one-shot gift exchange games.

In our context, the repetition of the situation may have the effect of increasing the salience of the market conditions, and so may increase the chance of a treatment effect. However, repetition may also lead to reputation effects. In our experimental procedures interaction took place under anonymity, so that no identification of the other person in a match is possible. In this sense, each interaction should be considered to be a separate event. However, a worker knows that she might be anonymously re-matched with the same firm, so that dynamic considerations may be relevant. In addition, perhaps the number of participants is small enough to attempt to maintain a group reputation.

Our focus in this study is on the existence of treatment effects from varying market conditions. Any such effect should not be influenced by the possible presence of reputation, i.e. a priori there is no reason to believe that market conditions will interact with reputation formation. Nevertheless, to verify that gift exchange itself is not entirely an artifact of repeated

\footnotetext{
${ }^{9}$ We thank Martin Dufwenberg and Georg Kirchsteiger for their clarifying comments in this regard.
} 
interaction we also conducted four sessions with pure one-shot gift exchange (no multiple periods).

Our 12 multi-period sessions consisted of four sessions of each of three treatments. In the excess supply of labor (hereafter, ESL) treatment, there were 12 workers and eight firms. In the excess supply of firms (hereafter, ESF) treatment, there were eight workers and 12 firms. Comparisons across these treatments corresponded to our investigation of the effects of market imbalance. In the minimum-wage (hereafter MW) treatment, we imposed a minimum wage when there were more workers than firms, the ESL case.

3.1 Design. In our multi-period sessions, we use the following simple symmetric and linear payoff functions:

$$
\begin{aligned}
& \mathrm{FI}=10-w+5 e \\
& \mathrm{WI}=10-e+5 w,
\end{aligned}
$$

where FI and WI refer (respectively) to firm income and worker income, $w$ denotes the wage and $e$ the effort level. The range of possible wage and effort levels is restricted to integers between 0 and 10, inclusive. Each unit of income was worth five pesetas ( $\$ 1 \square 150$ pesetas, at that time). When there was no minimum-wage requirement, a firm was free to propose any wage from zero up to the endowment of 10 . When we imposed a minimum wage, wage offers could range from five - the mid-point of the original range - to 10. A worker or a firm who remained unmatched in any period (due to the excess supply of labor or firms, respectively) retained his or her endowment of 10 for that period. 
The symmetry and the linearity of the payoff structure are the two crucial features of our design. The symmetry of the payoff functions is necessary to ensure that the impact of our treatment variables can be studied in isolation. ${ }^{10}$ It implies that, apart from issues of market conditions, the only difference between the incentives of the two players is caused by the fact that one of them chooses first and the other chooses second. It also makes it possible to think of a situation with $n$ firms and $m$ workers as symmetric to the case of $m$ firms and $n$ workers. ${ }^{11}$ Similarly, the symmetry makes it transparent how the minimum wage restricts firms' opportunities. Finally, given symmetry, equality of wage and effort yields a simple benchmark for evaluating the degree to which the second movers take a larger share for themselves.

The linearity of our payoff function simplifies the decision situation by making the marginal effect of effort independent of the wage. It will also facilitate the formulation of our null hypothesis below. Another important feature of our design is that the information available to participants was the same in all three treatments. All wage offers were public information both for firms and for workers, while only the parties directly involved knew the effort supplied in a particular match. $^{12}$

It is easy to verify that with these features the standard subgame-perfect equilibrium prediction does not depend on whether there are more firms or more workers in the market, or on

\footnotetext{
${ }_{11}^{10}$ An asymmetric representation could be easily introduced in subsequent experiments.

${ }^{11}$ Here the wage is not a pure one-to-one transfer, unlike the payoff design in Fehr, Kirchsteiger and Riedl (1993) and its successors. For our purposes, however, the crucial feature of the gift exchange game, from a conceptual point of view, is the sequential structure of the game and the fact that joint deviations can lead to common gains. Since we wished to maintain these two features and, at the same time, introduce symmetry, it was not possible to keep the one-to-one transfer aspect of the payoff structure. One can think of our design as representing the case where gifts are more valuable to the recipient than to the donor.

${ }^{12}$ An antecedent of our analysis of the state of competition is Fehr, Kirchler, Weichbold and Gächter (1998). They compare behavior in gift exchange markets with excess supply to behavior in a bilateral gift exchange condition. However, they use an asymmetric non-linear payoff function in both treatments and information about others' wage offers is different across the two treatments. Given these features, their data can not be used for our purposes.
} 
whether firms' choice set allows for more or less possibilities. In the second stage workers have no financial incentive to exert any effort. Given this expected behavior, the subgame-perfect equilibrium notion predicts that firms will offer a wage of zero (or five, with the minimum wage). As a consequence, without a minimum wage, all agents would receive payoffs of 10 , independently of the existence and type of market imbalance. When firms are required to offer a wage of at least five, the standard model predicts that firms each receive five, matched workers each receive 35 , and unmatched workers each receive 10 , the endowment.

In our four sessions with one-shot encounters, we used the payoff functions:

$$
\begin{gathered}
\mathrm{FI}=800-20 w+100 e \\
\mathrm{WI}=800-20 e+100 w,
\end{gathered}
$$

with 1 unit $=1$ peseta. To generate suitable final earnings for participants in a one-shot experiment the parameter values are different than those in (1) and (2). Observe, however, that the transformation rate between wage and effort is equal to 5 , just as in the previous payoff functions. The only difference is the size of the constant term; linearity and symmetry are preserved.

3.2 Procedures. The multi-period sessions took about two hours. At the beginning of each experimental session, all participants were gathered in one room and the instructions were read to them, while they read along. ${ }^{13}$ During this time subjects could ask public questions about the procedures. The participants were then randomly assigned to one of the roles, and workers and

\footnotetext{
${ }^{13}$ A copy of the instructions can be found at the Economic Journal website. With the exception of the payoff function they closely follow those of Fehr, Kirchsteiger and Riedl (1993).
} 
firms were seated in different rooms. Each period consisted of two stages: Stage 1 of each period consisted in a one-sided oral auction. Employers made wage offers and these offers were written on the blackboards of both rooms. In the ESL and ESF treatments, firms that had not made a wage offer received a payoff of 10; this gave them the same payoff than if they had made a wage offer of 0 and had then been matched with a worker who chose a 0 effort level. In the MW treatment firms were obligated to make an offer; if they offered the minimum wage of 5 they ensured themselves a payoff of 5 .

To accept an offer a worker had to raise his hand and state which of the outstanding offers he accepted. In Stage 2, each worker wrote his effort level on his record sheet. This information was then communicated exclusively to the corresponding firm. We excluded the possibility of workers rejecting wage offers. Our trading rules specified that, after the wage-offer stage of a period was over, workers who had not accepted a wage would be randomly assigned to the firms whose offers were still outstanding; it was actually never necessary in our sessions to assign subjects randomly according to this rule.

Payoffs in each of the 10 periods were aggregated to yield session payoffs. Subjects were paid privately at the end of the session; in addition to experimental earnings, each participant received 500 pesetas as a show-up fee. Average total earnings were about 2000 pesetas.

For the four single-period sessions, each session had an even number of participants (18, 18,14 and 16), with half randomly assigned the role of first movers (firms) and the other half assigned the role of second movers (workers). ${ }^{14}$ As in the multiple-period sessions, subjects

\footnotetext{
${ }^{14}$ These sessions did not involve any market interaction, since they were specifically thought of as controls for the dynamic aspects of the other sessions.
} 
were gathered in a room and the instructions were read to them while they read along. The single period developed as follows: First, each first mover decided separately on a wage offer. Each offer was then communicated to a randomly selected second mover, who then made an effort decision. After that the session was over; subjects were privately paid their earnings and left the room. The average payment in these half-hour sessions was approximately 1100 pesetas.

3.3 Hypotheses. Once a wage has been accepted, a worker maximizes his own period earnings by contributing no effort. Anticipating this, a firm should choose the lowest possible wage -0 in ESL and ESF and 5 in MW. Thus, according to the most standard view of economic behavior, both wages and effort levels will invariably be the minimum permitted. Embedding a game of this type in a market environment with competition does not alter the straightforward prediction of game-theoretic analysis. In an unbalanced market context some agents will not be matched, but this does not affect the pecuniary incentive structure of subjects given that they have been matched. This prediction represents the strong null hypothesis; however, to take into account the possibility of decision error we formulate a somewhat weaker null hypothesis.

Decision error can be conceptualized by presuming that subjects just make purely random mistakes in their decisions; alternatively, Anderson, Goeree and Holt (1998) posit that relatively costly mistakes are less likely. Note, however, that costs of deviations do not depend on the actions of others, given the linear structure of our payoff function; in addition, deviation costs are the same in all treatments. Thus, incorporating the notion of errors into the standard prediction leads to the following null hypothesis, composed of three elements:

$$
H_{0}:
$$


(i) Wage offers are the same under ESF than under ESL and lower than under MW. ${ }^{15}$

(ii) Effort levels are independent of wage levels in all treatments.

(iii) The relationship between wages and effort is the same in all treatments.

We now move to our alternative hypotheses. The anticipation of firms' wage offers is somewhat more complex than that of workers as it may involve both strategic and motivational elements. For example, one might expect that in a tighter labor market (ESF) the additional competitive pressure could lead to higher wages than in one with slack. On the other hand, if firms anticipate that workers would return a gift more generously under ESL, this might lead to higher wages under ESL than under ESF. Regarding the MW treatment, at first glance the wage restriction would appear to necessarily raise the average wage, but there may be countervailing forces. While the overall effect is not completely clear for either comparison, we feel that it is natural that the primary effect will dominate and formulate a one-sided alternative to portion (i) of the null hypothesis:

$H_{A i}$ : Wage offers in the ESL treatment will be lower than in the non-ESL treatments.

Current models of interdependent preferences predict that higher wages will lead to higher effort levels in all treatments, as is the case in all previous gift-exchange experiments. In line with all of these models, we formulate the alternative to portion (ii) of our null hypothesis:

$H_{\text {Aii }}: \quad$ Effort levels are increasing in wage levels in all treatments.

We conjectured earlier that there could be differences when comparing the ESL to either the ESF or the MW treatments. While menu dependence may stem from motives not captured by

\footnotetext{
${ }^{15}$ This assumes that errors are not so pervasive as to cause the prevailing wage under ESF and ESL to exceed five.
} 
the more formal models, the kindness-based models posit that the kindness of a wage offer reflects the range from which it was chosen. The ranges differ explicitly between the MW and ESL treatments, leading to one alternative to part (iii) of our null hypothesis:

\section{$H_{\text {Aiii }}(M W)$ : Worker responsiveness for wages will differ less across the range of intermediate and high wages in the MW treatment than in the ESL treatment}

With respect to the ESL-ESF comparison, if a worker felt that an intermediate wage was 'forced' by the competitive pressures in ESF, this wage would be perceived to be less kind than in the ESL treatment. Thus, a moderate wage in ESL may be considered kinder than the same wage in ESF or MW, while these models predict that a wage at the top of the range (10) is equally kind in all cases. So, worker responsiveness to wages could plausibly differ across treatments at moderate wages, but (according to the model) not at top wages, leading to the following alternative to part (iii) of the null hypothesis:

$H_{\text {Aiii }}(E S F)$ : Worker responsiveness for wages will differ less across the range of intermediate and high wages in the ESF treatment than in the ESL treatment.

For the sake of precision, we have chosen to formulate the last alternative hypothesis in terms of the relevant kindness-based models. However, as already mentioned, menu-dependence may take other forms than the one predicted by theory. In addition, the range-based notion of kindness may miss important aspects of the broader notion of kindness. Even though we have chosen these specific hypotheses, we are open to other comparisons of differences in behavior across treatments. 


\section{RESULTS}

The ESL, ESF, and MW results are displayed graphically in Figures I, II, and III, where the variable called wage refers to accepted wages.

[Figures I, II, and III about here]

The patterns are similar in the ESL and ESF treatments; in both cases the modal outcome is the firm offering a wage of 10 and the worker choosing an effort level of 10 . However, imposing a minimum wage of 5 has the effect of dramatically reducing the number of times that a wage of 10 is chosen. The height of the $(0,0)$ column in ESF is much smaller than in ESL, as few 0 wage proposals were accepted. Note the almost total lack of points to the southeast. In fact, there were only five occasions (three in ESL, one in ESF, and one in MW) where effort exceeded the wage. While there is a slight "ridge of reciprocation" along the 45-degree line, people very rarely respond to a "gift" with a larger "gift", even though this would increase the total payoff. However, there are many observations with 0 effort, even when the wage is 10 . This asymmetry leads to the workers earning, on average, substantially more than the firms do. ${ }^{16}$

Figure IV shows the average wage in our treatments over time, with separate series for offered wages and accepted wages in ESF; Figure V shows the average effort chosen over time.

\section{[Figures IV and V about here]}

We see that wages are generally fairly high, except that there appears to be a substantial drop in wages in the last period of the ESF and ESL treatments. As already mentioned, effort levels are substantially lower than wages, despite the symmetry of the payoff structure. The

\footnotetext{
${ }^{16}$ This is a familiar phenomenon in dilemma games of this nature. This fact may be surprising at first sight, but it is actually very much in line with social-preference models such as Bolton and Ockenfels (2000) and Fehr and
} 
differences between the three wage series appear to be quite small throughout the periods with accepted wages in ESF being slightly higher. While there is a spread in average effort in early periods, this diminishes over time. Average effort drops off in later periods, particularly in the ESF and ESL treatments.

\section{Descriptive Statistics}

Table 1 shows the average effort at each wage, along with the overall average (accepted) wage and the overall average effort in each of these treatments:

[Table 1 about here]

The average accepted wage offer in the ESF treatment was $8.36,12 \%$ higher than the 7.45 average wage in the ESL treatment. However, considering all wages offered in ESF (recall that 1/3 of the offers in ESF are left unmatched), the average is 7.35. By comparison, the average wage in the MW treatment is only slightly higher, at 7.82 , even though we preclude low wages. If we exclude wages lower than 5, the average wage in the ESL treatment is 8.76 and the average accepted wage in the ESF treatment is 9.02 .

Effort levels are a bit lower in ESL than in ESF, consistent with the slightly lower wages in ESL; the ratio of aggregate effort to aggregate wage is .527 for ESF and .516 for ESL. ${ }^{17}$ On the other hand, effort appears to be substantially lower when there is a minimum wage, and the effort/wage ratio is only .345 .

Schmidt (1999), and Charness and Rabin (2002). According to these models, second movers will tend to make choices that give themselves more than half.

${ }^{17}$ We also computed separate ratios for wages from 5-10, inclusive. There was virtually no difference for either ESF or ESL (.527 vs. .529 and .516 vs. .523, respectively). 
We can also distinguish among the treatments in terms of efficiency or in terms of cooperative gains. By efficiency, we refer to the proportion of maximum joint payoff that is achieved; cooperative gains are defined by both sides being better off after the interaction than before. Efficiency is highest (63.8\%) for the ESF treatment, lower $(56.5 \%)$ for the ESL treatment, and lowest $(52.6 \%)$ for the MW treatment. Cooperative gains are the rule with relatively high wages, although workers typically obtain a considerably larger share. The proportion of accepted wage offers that leads to cooperative gains is fairly similar across treatments: $55.3 \%$ for ESF, $53.4 \%$ for ESL, and 51.6\% for MW.

While we observe substantially positive effort levels in all of the ESF, ESL, and MW sessions, the question remains whether effort would drop to zero in a one-shot interaction. Table 2a shows the average wage and average effort level for each of our single-period sessions, while Table $2 \mathrm{~b}$ shows the distribution of wage offers in those sessions.

\section{[Tables $2 \mathrm{a}$ and $2 \mathrm{~b}$ about here]}

We see that the average effort level is 2.42, substantially lower than the ESL and ESF levels (3.85 and 4.41, respectively), but still somewhat higher than both the final round ESL and ESF values. However, the average wage offer is also lower in the single-period sessions; the average effort is $50.0 \%$ of the average wage, not much different than the $51.6 \%$ and $52.7 \%$ ratios in the ESL and ESF sessions, respectively, and actually greater than the $34.5 \%$ in the MW sessions. Average gift exchange is still sizable; the sum of first and second movers' average contributions (6.27) is more than $30 \%$ of the maximum feasible level (20).

As with the ESL and ESF treatments, 0 and 10 are the most frequent wage levels and there is some additional bunching for intermediate wage levels. The average wage is 4.84 , lower 
than the average wage in the ESL and ESF treatments, but in line with the final-round wage offers in these treatments. ${ }^{18}$

\section{Statistical analysis}

The statistical analysis of data from gift-exchange experiments with repeated interaction like the ones we conducted is a delicate matter. Due to the interaction between subjects across periods we only have, in the strict sense, one statistically-independent observation per session. Our analysis primarily consists of nonparametric tests performed on these data points and random-effects ordered-probit regressions, which take into account multiple observations. We present these alternative test results below.

\section{Nonparametric tests}

Table 3 presents session-level data on average wages and effort in our multi-period sessions. In the first three rows, we consider average effort in low, medium, and high wage ranges. The last three rows give average wages and average effort, as well as the effort/wage ratio.

[Table 3 about here]

Wages and effort levels appear to be positively related. To provide some statistical validity for this reciprocity in actions we used the Page test on the basis of the ESF and ESL session level data. For each session we computed the mean effort level for four wage ranges: 0 to 4, 5 to 8,9 and $10 .{ }^{19}$ For these two treatments, we can reject the null hypothesis of no relation

\footnotetext{
${ }^{18}$ Of course, this average of 4.84 is inevitably lower than in the MW $=5$ case.

${ }^{19}$ At the session level we do not always have observations for each wage level. For this reason, we group the data into wage ranges. For a reference to the Page test see Siegel and Castellan (1988). It tests the hypothesis that $k$ matched groups are the same versus the alternative hypothesis that the groups are ordered in a specific sequence.
} 
between wage and effort levels in favor of the alternative of an increasing relation at the $1 \%$ level; for the MW treatment a simple binomial test yields the same conclusion.

Table 4 shows the results of permutation tests, on wages, effort levels and effort/wage ratios, using session-level data, across pairs of treatments. ${ }^{20}$

\section{[Table 4 about here]}

For wages, no comparison of session-level averages shows a difference close to conventional levels. We also examine the statistical significance of the disparity between the frequency of offers at the lowest and highest wage. Using the permutation test across the ESF and ESL treatments, we do not find significant differences in the proportions of wages equal to zero or in the proportion of wages equal to ten. However, the permutation test on session-level data indicates that the proportion of wages equal to ten is lower ( $p=0.057$, one-tailed test) when there is a minimum wage. ${ }^{21}$ In summary, the actions of the first-movers of our experimental markets do not appear to be highly sensitive to whether there is excess supply or excess demand, but the imposition of a minimum wage decreases the proportion of top wages paid.

With respect to average effort levels in each session, while we observe generally lower effort levels in ESL than in ESF, the permutation test does not find any significant differences between treatments. The permutation test does not reject the hypothesis that average effort levels in the MW treatment are the same than in ESL at conventional statistical levels; however, the probability with these few observations is on the verge of being marginally significant.

\footnotetext{
${ }^{20}$ In contrast to the Wilcoxon rank-sum test, the permutation test also takes into account the differences between the data for the two treatments. For a discussion of the use of the permutation test in experimental economics see Davis and Holt (1993).

${ }^{21}$ Interestingly, while the median wage offer was 9 under both ESL and ESF (and the median accepted wage under ESF was 10), imposing a minimum wage lowers the median wage offer to 8 .
} 
Where we do find a clear treatment effect is for the comparison of effort/wage ratios. While there is little or no difference between the effort/wage ratio in ESL and ESF, the test shows a significant difference between this ratio in the ESL and MW treatments. Thus, the minimum wage seems to make workers less responsive to wages in general.

\section{Regression Analysis}

While nonparametric tests are very clean, they may lack some of the power of the more conventional regression-analysis approach. We use a random-effects ordered probit model to accommodate our discrete data and multiple observations. Although this is based on a number of assumptions about the covariance structure, some of which may not be fully satisfied for our data, it provides a good tool to explore the apparent difference between treatments in the rate at which effort levels increase with wage levels.

Tables $5 \mathrm{a}$ and $5 \mathrm{~b}$ present the results of these regressions, which all include period dummies (period 6, an arbitrary middle period, is the baseline) and treatment dummies. Observe that for the regressions where effort is the dependent variable we present separate specifications with wages only between 5 and 10 . These specifications highlight the change in responsiveness to intermediate and high wages, the range where the kindness-based models may have some bite. $^{22}$ In addition, this specification provides a meaningful test of the intercept terms in the regressions.

[Tables $5 \mathrm{a}$ and $5 \mathrm{~b}$ about here]

\footnotetext{
${ }^{22}$ Since only wages between 5 and 10 are feasible in the MW treatment, it seems appropriate to compare effort responses to ESL wages in the same range.
} 
Consistent with the impressions one gets from the inspection of Figures IV and V, there are some significant period effects. For regressions in which effort is the dependent variable, there is always a significantly negative coefficient for the period-10 dummy, and the period- 9 dummy is always negative and usually significant. Wages appear to build over the first few periods, until they decline again in the tenth period.

In the ESL vs. ESF comparison, there is a modest (but not significant) difference across treatments in the average accepted wage. With respect to effort, specification (4) shows that there does exist a significant overall treatment difference. However, specifications (2) and (3) reveal that this is due to the strong reaction of effort to wages. The latter specifications show a strong relationship between the wage accepted and the effort level chosen, whereas neither the pure treatment dummy, nor the difference in the relationship between effort and wage are significant across treatments.

In the ESL vs. MW comparison, shown in Table 5b, there is no significant difference in wages across treatment when we consider all wages. However, if we consider only wages of at least five, the average wage is significantly higher in the ESL treatment. Once again, we see the strong relationship between the wage accepted and the effort chosen. There is also a marginally significant negative coefficient on the MW treatment dummy in specification (4), where we discard ESL wages less than 5, for better comparability with the MW treatment. As before, there is no significant difference across treatments in the relationship between effort and wage. Overall effort is seen to be significantly lower in the MW treatment, when we compare effort in response to wages of 5 or more. 


\section{DISCUSSION}

Let us consider the data in the light of our hypotheses. Wage offers are similar in the ESL and ESF treatments, in contrast to $H_{A i}$, although the effective wage paid is indeed a bit higher in the tighter labor market. We can easily reject part (ii) of the null hypothesis in favor of the alternative $H_{A i i}$; effort levels are increasing in wages. These results are entirely consistent with previous gift-exchange studies.

We wish to specially highlight the findings pertaining to our third alternative hypothesis. Recall that some social-preference models claim that financial sacrifice is motivated only by distributional concerns, so that menu dependence is irrelevant. In this case, there should be no difference across treatments in the effort/wage relationship, since the effort chosen at a particular wage will be the same regardless of the path leading to the choice. On the other hand, the formal kindness-based models of reciprocity predict that if intermediate wages are perceived as less kind in the ESF or MW treatments than in the ESL treatment, there will be less sacrifice at these wages in the non-ESL treatments.

Imposing a minimum wage does appear to substantially reduce the effort level for intermediate wages. However, Table 1 shows that this also has the effect of reducing effort for even the highest wages. Overall, the average effort chosen in the ESL treatment is about $50 \%$ higher than in the MW treatment, and the average effort/wage ratio is marginally significantly lower (Table 4, last line) in the MW treatment than in the ESL treatment, even with the few session-level observations available.

While there appears to be lower effort in the MW treatment, the pattern of worker responsiveness is not consistent with the Dufwenberg and Kirchsteiger (forthcoming) model. To 
see this, recall that the perceived kindness of a wage depends on the feasible range; a wage of 5 is as unkind as possible in the MW treatment, but neither kind nor unkind in the ESL treatment (since 5 is the average of the $[0,10]$ wage range). If financial sacrifice here is inspired by such kindness considerations, there should be lower effort at intermediate wages in the MW treatment. But since the model presumes that a wage of 10 is equally kind in all cases, there should be a greater difference in the MW treatment in effort at intermediate vs. high wages than in the ESL treatment. This should be reflected in regressions on effort against wages in this range.

However, specification (4) in Table 5b shows that while the coefficient for the intercept term is significant ( $p=0.039$, for the one-tailed test appropriate for the ex ante prediction), the coefficient for the interaction term is not at all close to being statistically significant. ${ }^{23}$ Thus, the lower overall effort in the MW treatment (specification (6) in Table 5b shows strong significance for the MW dummy) is a feature for the full wage range. This does indicate that some form of menu dependence is present, although not the form described in the range-based kindness models.

For the ESF vs. ESL comparison, it is perhaps surprising that the chosen wages do not differ dramatically across treatments. Since a similar pattern of wage offers across treatments might cause workers (in a between-subjects comparison) to feel the same way about a particular wage, it is possible that perceived kindness does not differ much across treatments. If the degree of perceived kindness of a wage does not differ across the ESF and ESL treatments, we should not expect the patterns of worker responsiveness to differ. Nevertheless, accepted wage levels are indeed moderately higher in the ESF treatment than in the ESL treatment (8.36 vs. 7.45).

\footnotetext{
${ }^{23}$ The coefficient on the interaction term is also far from significant in the regression using the full ESF wage range, specification (3) in Table $5 \mathrm{~b}$.
} 
Specification (1) in Table 5a shows that this difference is marginally significant $(\mathrm{Z}=1.42, p=$ 0.078, one-tailed test).

None of the strict nonparametric tests in Table 4 show any differences between the ESF and ESL treatments. In addition, the regressions in specifications (2) and (3) of Table 5a show few differences between the ESL and ESF treatments. The ESF dummy is not significantly different than 0 . While the coefficient for the ESF wage-interaction term is not significantly different than 0 , it is slightly negative. This is the sign predicted by the Dufwenberg and Kirchsteiger (forthcoming) model given a more limited 'feasible' wage range (as defined by positive wages with a reasonable chance of being profitable) than in the ESF treatment. ${ }^{24}$

In any event, the ESF vs. ESL comparison does not suggest a kindness-based difference in responsiveness. However, since the pattern of wages is not strongly divergent and perceived kindness may not differ across treatments, we are reluctant to conclude that the observed difference indicates a rejection of the model. It may also be a bit unrealistic to expect to identify the requisite slope effect with the data at hand. In a general sense, perhaps the observed behavior is consistent with a broader notion of kindness, since many people might well consider lowering wages when there are excess workers to be a form of exploitation. ${ }^{25}$

In any case, the combined data from our three treatments suggests that effort responses reflect distributional preferences more than kindness-based positive reciprocity as formulated.

\footnotetext{
${ }^{24}$ If a worker suspects that the motivation behind a wage is to respond strategically to competitive pressure, he might be inclined to be less generous in return, making low positive wages 'not feasible'. Using the data in Table 1 , it is easy to calculate that, on average, any positive wage below 5 loses money in the ESF treatment, while every positive wage except 4 is profitable in the ESL treatment. Choosing the minimum wage roughly breaks even in the MW treatment.

${ }^{25}$ Campbell and Kamlani (1997) and Bewley (1999) find that personnel managers indicate that firms are reluctant to cut wages when there is an excess supply of workers, fearing that workers will perceive such cuts as unfair and hostile.
} 
Formal models of social preferences that do not include positive reciprocity, such as Fehr and Schmidt (1999), Bolton and Ockenfels (2000), and Charness and Rabin (2002), can explain gift exchange as an equilibrium phenomenon and, in general terms, fit together well with our data. However, perhaps there is something in our data that suggests the need to go beyond models of the type just mentioned, as behavior seems menu-dependent in at least the MW treatment.

The reduction in effort in the MW treatment is fairly uniform over the wage range, so that it is worker generosity (rather than a response to perceived kindness) that is impacted. While not predicted by any of the leading models of social preferences, the reductions in effort and in the proportion of top wages paid in the MW treatment are consistent with the responsibilityalleviation in Charness (2000). This idea says that people will act in a more generous (or honest) manner when the full weight of responsibility for an outcome rests upon their own shoulders. Being 'forced to be generous' by the presence of a minimum wage means that workers are not as responsive to the wages offered; in addition, firms themselves are reluctant to offer top wages under these circumstances. On the other hand, changing the state of competition to an excess supply of firms does not have much effect on either worker or firm behavior.

On further reflection it appears that conceiving of behavior in gift exchange-markets fundamentally in terms of the rewarding of perceived kindness may lead to a bit of a paradox. Kindness-based positive reciprocity implies that workers expend effort to reward wage levels that they perceive to be kind. But to appear truly kind, a wage should surely be above the one that yields the highest profits for firms. In our data this is actually not possible, since the ex post 
profit-maximizing wage is 10 in all treatments. ${ }^{26}$ More generally, however, if certain wage levels that are perceived as kind are sufficiently reciprocated, then they may themselves become the profit-maximizing ones. This reflection is in line with our data being roughly consistent with models that do not incorporate this kind of positive reciprocity.

The results from our single-period sessions are similar in spirit to those in the ESL and ESF treatments, demonstrating that repeated interaction is not required for gift exchange. However, the reduced wage and effort levels, as well as the decay seen in the ESL and ESF sessions, suggest that behavior may have been influenced by some type of strategic consideration, perhaps such as group reputation-building. ${ }^{27}$ Nevertheless, the average firm income in period 10 is still substantially larger than the equilibrium prediction, in both treatments.

\section{CONCLUSION}

One principal finding is that in our data the differences between our ESL and ESF treatments are minor, in that whether firms or workers are on the long or short side of the market generally does not have a major impact on their behavior. The intuitive notion that being on the long or short side of the market will affect people's disposition towards others is not supported by our data.

As discussed in detail in section 4, we find very considerable deviations from the standard prediction. Our results exhibit a clear pattern of reciprocal actions, as in previous work on gift

\footnotetext{
${ }^{26}$ Of course, this does not address the question of why a wage of 10 is expected (ex post) to maximize firm income.

${ }^{27}$ Charness, Frechette, and Kagel (forthcoming) also observe substantial decay in gift exchange in the last periods of their experimental session.
} 
exchange. We also find that subjects are able to attain considerable cooperative gains. Thus, the absence of an ESL-ESF treatment effect is not the result of laboratory behavior conforming to the standard game-theoretic prediction.

The other main result is the significant impact of imposing a minimum wage. Although the positive relationship between wage and effort is the same when a minimum wage is imposed as when it isn't, the intervention has a negative effect on effort provision (productivity). We feel that this result is not only interesting as an instance of menu dependence, but also has some policy relevance. The question is how much credence can be given to our result in this respect.

One possibility is that our experiments have just picked up a rather short-term emotional response to the minimum wage. If so, perhaps such an effect might just disappear after an initial period (as one's sense of entitlement adjusts) and, hence, would probably not be registered by appropriate field data. One may even speculate that experiments using the strategy-elicitation procedure - which tends to evoke more thoughtful behavior - would not find the minimum wage effect. However, it would be very hard to actually check the above possibility with field data due to the multitude of intervening factors.

Our evidence can be put into perspective by relating it to the cited evidence favoring the notion that non-outcome information influences behavior. A provisional assessment of this evidence points to several patterns: First, non-outcome information tends to be more relevant when it very directly points to others' personal responsibility, as in the cases analyzed by Charness (forthcoming) and Brandts and Charness (2003). Second, perhaps due to a form of selfserving bias, people may react more strongly to perceived negative intentions (which may play 
no role in our context) than to perceived positive intentions. ${ }^{28}$ Third - and perhaps most importantly - motivation and behavior cannot always be separated from issues of cognition and perception. Some menu alternations may just be naturally more salient and jump more readily to people's eye than others. The interplay of cognition and motivation is rather unexplored terrain at this point, but may actually be of considerable importance for understanding social and economic life. We feel that empirical data - among it experimental data like ours - will be an essential input in this regard.

On the basis of our interpretation of this previous evidence, the modest treatment effects we found in this paper appear to make sense. The attribution of disposition on the basis of the type of market-balance can only be based on a rather indirect channel, while the presence of a minimum wage is rather paramount in the minds of the workers. With competitive bidding, the attribution of responsibility is muted, potentially explaining why the direction of market imbalance does not seem to be a strong force in our data. In contrast, the way a minimum wage restricts firms' choice set is rather transparent. Our results suggest that models of interdependent preferences may not need to take into account the effects of market imbalance on motivation, but that the issue of responsibility and generosity perhaps should be considered.

\footnotetext{
${ }^{28}$ See Offerman (2002).
} 


\section{REFERENCES}

Akerlof, George (1982), "Labor Contracts as Partial Gift Exchange," Quarterly Journal of Economics, 97, 543-69.

Anderson, Simon, Jacob Goeree and Charles Holt (1998), "A Theoretical Analysis of Altruism and Decision Error in Public Good Games," Journal of Public Economics, 70, 297-323.

Berg, Joyce, John Dickhaut and Kevin McCabe (1995), "Trust, Reciprocity and Social History," Games and Economic Behavior, 10, 1, 122-142.

Bewley, Truman (1999), Why Wages Don't Fall during a Recession, Cambridge, MA: Harvard University Press.

Blount, Sally (1995), “When Social Outcomes Aren't Fair: The Effect of Casual Attributions on Preferences," Organizational Behavior and Human Decision Processes, 63, 2, 131-144.

Bolton, Gary, Jordi Brandts and Axel Ockenfels (1998), "Measuring Motivations for the Reciprocal Responses Observed in a Simple Dilemma Game," Experimental Economics, 1, 207-219.

Bolton, Gary and Axel Ockenfels (2000), "ERC: A Theory of Equity, Reciprocity and Competition," American Economic Review, 90, 166-193.

Bowles, Samuel (1998), "Endogenous Preferences: The Cultural Consequences of Markets and other Economic Institutions," Journal of Economic Literature, 36, 75-111.

Brandts, Jordi and Gary Charness (2003), "Truth or Consequences: An Experiment," Management Science, 49, 116-130.

Brandts, Jordi and Carles Solà (2001), "Reference Points and Negative Reciprocity in Simple Sequential Games," Games and Economic Behavior, 36, 138-157.

Brown, Martin, Armin Falk and Ernst Fehr (2002), "Contractual Incompleteness and the Nature of Market Interactions," mimeo.

Campbell, Carl III and Kunal Kamlani (1997), "The Reasons for Wage Rigidity: Evidence from a Survey of Firms," Quarterly Journal of Economics, 112, 253-261.

Card, David and Alan Krueger (1995), Myth and Measurement: The New Economics of the Minimum Wage, Princeton N.J.: Princeton University Press.

Cason, Timothy and Vai-Lam Mui (1998), "Social Influence in the Sequential Dictator Game," Journal of Mathematical Psychology, 42, 248-265.

Charness, Gary (forthcoming), "Attribution and Reciprocity in an Experimental Labor Market," Journal of Labor Economics.

Charness, Gary (2000), "Responsibility and Effort in an Experimental Labor Market," Journal of Economic Behavior and Organization, 42, 3, 375-384. 
Charness, Gary, Guillaume Frechette, and John Kagel (forthcoming), "How Robust is Laboratory Gift Exchange?," Experimental Economics.

Charness, Gary and Matthew Rabin (2002), "Understanding Social Preferences with Simple Tests," Quarterly Journal of Economics 117, 817-869.

Clark, Kenneth and Martin Sefton (2001), "The Sequential Prisoner's Dilemma: Evidence on Reciprocation," Economic Journal, 111, 51-68.

Davis, Douglas and Charles Holt (1993), Experimental Economics, Princeton, NJ: Princeton University Press.

Dufwenberg, Martin and Georg Kirchsteiger (forthcoming), "A Theory of Sequential Reciprocity," Games and Economic Behavior.

Falk, Armin, Ernst Fehr, and Urs Fischbacher (forthcoming), "On the Nature of Fair Behavior," Economic Inquiry,.

Falk, Armin, Ernst Fehr, and Christian Zehnder (2002), "The Behavioral Effects of Minimum Wages," mimeo.

Fehr, Ernst and Armin Falk (1999), "Wage Rigidity in a Competitive Incomplete Contract Market," Journal of Political Economy, 107, 106-134.

Fehr, Ernst, Simon Gächter and Georg Kirchsteiger (1997), "Reciprocity as a Contract Enforcement Device: Experimental Evidence,” Econometrica, 65, 4, 833-860.

Fehr, Ernst, Erich Kirchler, Andreas Weichbold and Simon Gächter (1998), "When Social Norms Overpower Competition: Gift Exchange in Experimental Labor Markets," Journal of Labor Economics, 16, 4, 324-351.

Fehr, Ernst, Georg Kirchsteiger and Arno Riedl (1993), "Does Fairness Prevent Market Clearing? An Experimental Investigation,” Quarterly Journal of Economics, 108, 2, 437-460.

Fehr, Ernst, Georg Kirchsteiger and Arno Riedl (1998), "Gift Exchange and Reciprocity in Competitive Experimental Markets," European Economic Review, 42, 1-34.

Fehr, Ernst and Klaus Schmidt (1999), "A Theory of Fairness, Competition and Cooperation," Quarterly Journal of Economics, 114, 817-868.

Hannan, R. Lynn, John Kagel, and Donald Moser (2002), "Partial Gift Exchange in Experimental Labor Markets: Impact of Subject Population Differences, Productivity Differences and Effort Request on Behavior," Journal of Labor Economics, 20, 923-951.

Lane, Robert (1991), The Market Experience, Cambridge: Cambridge University Press.

Offerman, Theo (2002) "Hurting Hurts More than Helping Helps," European Economic Review, 46, 1423-1437.

Rabin, Matthew (1993), "Incorporating Fairness into Game Theory and Economics," American Economic Review, 83, 1281-1302. 
Rabin, Matthew (1998), "Psychology and Economics," Journal of Economic Literature, 36, 11-46.

Roth, Alvin, Vesna Prasnikar, Masahiro Okuno-Fujiwara, and Shmuel Zamir (1991), "Bargaining and Market Behavior in Jerusalem, Ljubljana, Pittsburgh and Tokyo: An Experimental Study," American Economic Review, 81, 1068-1095.

Sadiraj, Klarita and Arthur Schram (1999), "Informed and Uninformed Investors in an Experimental Ponzi Scheme," Mimeo, University of Amsterdam.

Sen, Amartya (1997), "Maximization and the Act of Choice," Econometrica, 65, 745-779.

Siegel, Sidney and N. John Castellan, Jr. (1988), Nonparametric Statistics for the Behavioral Sciences. New York: McGraw-Hill. 
Table 1 - Average Effort at each Wage, by Multi-period Treatment

\begin{tabular}{|c|c|c|c|}
\hline Wage & ESF & ESL & MW \\
\hline 0 & $0.00(18)$ & $0.00(41)$ & --- \\
\hline 1 & $0.00(3)$ & $0.33(3)$ & --- \\
\hline 2 & $---\quad(0)$ & $0.80(5)$ & --- \\
\hline 3 & $0.00(1)$ & $0.67(6)$ & --- \\
\hline 4 & $0.50(4)$ & $0.67(9)$ & --- \\
\hline 5 & $1.45(20)$ & $2.20(15)$ & $1.03(37)$ \\
\hline 6 & $1.38(16)$ & $2.90(10)$ & $1.61(38)$ \\
\hline 7 & $1.64(14)$ & $2.71(14)$ & $2.58(69)$ \\
\hline 8 & $2.70(30)$ & $4.12(25)$ & $2.86(57)$ \\
\hline 9 & $4.91(22)$ & $4.64(36)$ & $3.13(39)$ \\
\hline 10 & $5.96(192)$ & $5.40(156)$ & $3.75(80)$ \\
\hline Average effort & $4.40(320)$ & $3.84(320)$ & $2.69(320)$ \\
\hline Average wage & $8.36(320)$ & $7.45(320)$ & $7.82(320)$ \\
\hline Agg. effort/wage & .527 & .515 & .345 \\
\hline
\end{tabular}


Table 2a - Average Wages and Effort in Single-period Sessions

\begin{tabular}{|c|c|c|c|c|c|}
\hline & $\begin{array}{c}\text { Session S-1 } \\
(9)\end{array}$ & $\begin{array}{c}\text { Session S-2 } \\
(9)\end{array}$ & $\begin{array}{c}\text { Session S-3 } \\
(7)\end{array}$ & $\begin{array}{c}\text { Session S-4 } \\
(8)\end{array}$ & $\begin{array}{c}\text { Overall } \\
(33)\end{array}$ \\
\hline $\begin{array}{c}\text { Average } \\
\text { wage }\end{array}$ & 6.44 & 5.11 & 5.00 & 3.25 & 4.85 \\
\hline $\begin{array}{c}\text { Average } \\
\text { effort }\end{array}$ & 4.33 & 2.67 & 1.29 & 1.00 & 2.42 \\
\hline
\end{tabular}

The numbers of observations are in parentheses.

Table $2 b$ - Distribution of Single-period Session Wages

\begin{tabular}{|c|c|c|c|c|c|c|c|c|c|c|c|}
\hline Wage levels & 0 & 1 & 2 & 3 & 4 & 5 & 6 & 7 & 8 & 9 & 10 \\
\hline $\begin{array}{c}\# \text { of } \\
\text { observations }\end{array}$ & 8 & 2 & 1 & 1 & 3 & 7 & 0 & 1 & 0 & 1 & 9 \\
\hline $\begin{array}{c}\text { Average } \\
\text { effort levels }\end{array}$ & 1.5 & 0 & 2 & 4 & 1.3 & 3.1 & - & 0 & - & 6 & 3.8 \\
\hline
\end{tabular}


Table 3- Average Wage and Effort, by Session

\begin{tabular}{|c|c|c|c|c|c|c|c|c|c|c|c|c|}
\hline & $\begin{array}{c}\text { ESF } \\
1 \\
\end{array}$ & $\begin{array}{c}\text { ESF } \\
2 \\
\end{array}$ & $\begin{array}{c}\text { ESF } \\
3 \\
\end{array}$ & $\begin{array}{c}\text { ESF } \\
4 \\
\end{array}$ & $\begin{array}{c}\text { ESL } \\
1 \\
\end{array}$ & $\begin{array}{c}\text { ESL } \\
2 \\
\end{array}$ & $\begin{array}{c}\text { ESL } \\
3 \\
\end{array}$ & $\begin{array}{c}\text { ESL } \\
4 \\
\end{array}$ & $\begin{array}{c}\text { MW } \\
1 \\
\end{array}$ & $\begin{array}{c}\mathrm{MW} \\
2 \\
\end{array}$ & $\begin{array}{c}\mathrm{MW} \\
3\end{array}$ & $\begin{array}{c}\text { MW } \\
4 \\
\end{array}$ \\
\hline $\begin{array}{l}\text { Avg. effort, } \\
\text { wages } 0-4\end{array}$ & - & 0.00 & 0.00 & 0.22 & 1.14 & 0.00 & 0.12 & 0.22 & - & - & - & - \\
\hline $\begin{array}{c}\text { Avg. effort, } \\
\text { wages 5-8 }\end{array}$ & - & 1.77 & 1.56 & 2.64 & 5.62 & 3.17 & 1.46 & 2.59 & 3.07 & 1.45 & 1.77 & 2.43 \\
\hline $\begin{array}{l}\text { Avg. effort, } \\
\text { wages 9-10 }\end{array}$ & 8.44 & 3.19 & 3.72 & 5.65 & 6.07 & 5.17 & 5.52 & 2.68 & 4.78 & 3.74 & 2.74 & 2.89 \\
\hline $\begin{array}{l}\text { Avg. wage. } \\
\text { session }\end{array}$ & $\begin{array}{l}9.66 \\
10.0\end{array}$ & $\begin{array}{l}5.91 \\
7.54\end{array}$ & $\begin{array}{l}6.24 \\
7.91\end{array}$ & $\begin{array}{l}7.57 \\
7.98\end{array}$ & 8.82 & 8.46 & 7.59 & 4.92 & 7.54 & 8.04 & 7.55 & 8.16 \\
\hline $\begin{array}{l}\text { Avg. effort, } \\
\text { session }\end{array}$ & 8.44 & 2.61 & 2.36 & 4.21 & 5.56 & 4.46 & 3.81 & 1.55 & 3.62 & 2.54 & 2.00 & 2.56 \\
\hline $\begin{array}{c}\text { Aggregate } \\
\text { effort/wage } \\
\text { ratio }\end{array}$ & .844 & .346 & .299 & .528 & .630 & .527 & .502 & .315 & .481 & .316 & .265 & .323 \\
\hline
\end{tabular}

In the ESF sessions, average accepted wages are shown in italics, below the average wage offers. 
Table 4- Permutation Tests on Session-level Data

\begin{tabular}{|c|c|c|}
\hline Measure & $\begin{array}{c}\text { Probability, } \\
\text { ESF vs. ESL }\end{array}$ & $\begin{array}{c}\text { Probability, } \\
\text { MW vs. ESL }\end{array}$ \\
Average wage offered & $0.914(0.457)$ & $0.886(0.443)$ \\
Average wage accepted & $0.514(0.257)$ & $0.886(0.443)$ \\
Average effort & $0.800(0.600)$ & $0.286(0.143)$ \\
Average effort, wage 5-8 & $0.686(0.657)$ & $0.343(0.171)$ \\
Average effort, wage 9-10 & $0.286(0.571)$ & $0.200(0.100)$ \\
Aggregate effort/wage ratio & $0.829(0.586)$ & $0.114(0.057)$ \\
\hline
\end{tabular}

Probabilities in parentheses reflect one-tailed tests; all others reflect two-tailed tests 
Table 5a - Random-efforts Ordered Probit Regressions, ESL vs. ESF

\begin{tabular}{|c|c|c|c|c|}
\hline \multirow{2}{*}{$\begin{array}{c}\text { Independent } \\
\text { variables }\end{array}$} & \multicolumn{4}{|c|}{ Dependent Variable } \\
\hline & $\begin{array}{l}\text { Wage } \\
(1)\end{array}$ & $\begin{array}{l}\text { Effort } \\
(2)\end{array}$ & $\begin{array}{c}\text { Effort* } \\
(3)\end{array}$ & $\begin{array}{c}\text { Effort } \\
(4)\end{array}$ \\
\hline ESF & $\begin{array}{c}.350 \\
(1.42)\end{array}$ & $\begin{array}{c}.346 \\
(0.65)\end{array}$ & $\begin{array}{c}.329 \\
(0.94)\end{array}$ & $\begin{array}{c}.614 \\
(2.91)\end{array}$ \\
\hline Wage & - & $\begin{array}{c}.384 \\
(10.4)\end{array}$ & $\begin{array}{c}.375 \\
(6.21)\end{array}$ & - \\
\hline ESF*Wage & - & $\begin{array}{c}-.030 \\
(-0.52)\end{array}$ & $\begin{array}{c}-.063 \\
(-0.84)\end{array}$ & - \\
\hline Period 1 & $\begin{array}{l}-1.297 \\
(-5.38)\end{array}$ & $\begin{array}{c}.434 \\
(1.83)\end{array}$ & $\begin{array}{c}.198 \\
(0.77)\end{array}$ & $\begin{array}{c}-.473 \\
(-2.21)\end{array}$ \\
\hline Period 2 & $\begin{array}{c}-.852 \\
(-3.60)\end{array}$ & $\begin{array}{c}.064 \\
(0.28)\end{array}$ & $\begin{array}{c}.043 \\
(0.18)\end{array}$ & $\begin{array}{c}-.079 \\
(-0.37)\end{array}$ \\
\hline Period 3 & $\begin{array}{c}-.627 \\
(-2.58)\end{array}$ & $\begin{array}{c}.440 \\
(1.96)\end{array}$ & $\begin{array}{c}.369 \\
(1.58)\end{array}$ & $\begin{array}{c}.152 \\
(0.70)\end{array}$ \\
\hline Period 4 & $\begin{array}{c}-.736 \\
(-3.02)\end{array}$ & $\begin{array}{c}.375 \\
(1.63)\end{array}$ & $\begin{array}{c}.402 \\
(1.70)\end{array}$ & $\begin{array}{c}.105 \\
(0.48)\end{array}$ \\
\hline Period 5 & $\begin{array}{c}-.355 \\
(-1.42)\end{array}$ & $\begin{array}{c}.139 \\
(0.61)\end{array}$ & $\begin{array}{c}.086 \\
(0.37)\end{array}$ & $\begin{array}{c}.099 \\
(0.45)\end{array}$ \\
\hline Period 7 & $\begin{array}{c}-.444 \\
(-1.80)\end{array}$ & $\begin{array}{c}.077 \\
(0.34)\end{array}$ & $\begin{array}{c}.032 \\
(0.14)\end{array}$ & $\begin{array}{c}-.065 \\
(-0.30)\end{array}$ \\
\hline Period 8 & $\begin{array}{c}-.445 \\
(-1.81)\end{array}$ & $\begin{array}{c}-.382 \\
(-1.66)\end{array}$ & $\begin{array}{c}-.432 \\
(-1.85)\end{array}$ & $\begin{array}{c}-.353 \\
(-1.58)\end{array}$ \\
\hline Period 9 & $\begin{array}{c}-.319 \\
(-1.28)\end{array}$ & $\begin{array}{c}-.986 \\
(-4.21)\end{array}$ & $\begin{array}{l}-1.015 \\
(-4.28)\end{array}$ & $\begin{array}{c}-.842 \\
(-3.76)\end{array}$ \\
\hline Period 10 & $\begin{array}{l}-1.805 \\
(-7.40)\end{array}$ & $\begin{array}{l}-1.502 \\
(-5.29)\end{array}$ & $\begin{array}{c}-1.551 \\
(-5.35)\end{array}$ & $\begin{array}{l}-1.774 \\
(-6.91)\end{array}$ \\
\hline $\mathrm{N}$ & 632 & 640 & 550 & 640 \\
\hline LL & -897 & -911 & -869 & -1003 \\
\hline
\end{tabular}

Z-statistics in parentheses; ESF $=1$ for excess-firm data and $\mathrm{ESF}=0$ otherwise. Specifications marked by $\left(^{*}\right)$ consider only data from wages greater than 4 .

Bold indicates significance at the 5\% level, two-tailed test. 
Table 5b - Random-effects Ordered Probit Regressions, ESL vs. MW

\begin{tabular}{|c|c|c|c|c|c|c|}
\hline \multirow{2}{*}{$\begin{array}{l}\text { Independent } \\
\text { variables }\end{array}$} & \multicolumn{6}{|c|}{ Dependent Variable } \\
\hline & $\begin{array}{l}\text { Wage } \\
\text { (1) }\end{array}$ & $\begin{array}{l}\text { Wage* } \\
\text { (2) }\end{array}$ & $\begin{array}{c}\text { Effort } \\
\text { (3) }\end{array}$ & $\begin{array}{c}\text { Effort* } \\
\text { (4) }\end{array}$ & $\begin{array}{l}\text { Effort } \\
\text { (5) }\end{array}$ & $\begin{array}{l}\text { Effort* } \\
\text { (6) }\end{array}$ \\
\hline MW & $\begin{array}{c}-.352 \\
(-1.56)\end{array}$ & $\begin{array}{r}-1.166 \\
(-5.97)\end{array}$ & $\begin{array}{c}-.725 \\
(-1.21)\end{array}$ & $\begin{array}{c}-.714 \\
(-1.76)\end{array}$ & $\begin{array}{c}-.355 \\
(-1.22)\end{array}$ & $\begin{array}{c}-.773 \\
(-2.61)\end{array}$ \\
\hline Wage & - & - & $\begin{array}{c}.408 \\
(10.7)\end{array}$ & $\begin{array}{c}.382 \\
(6.29)\end{array}$ & - & - \\
\hline MW*Wage & - & - & $\begin{array}{c}.043 \\
(0.75)\end{array}$ & $\begin{array}{c}.055 \\
(0.74)\end{array}$ & - & - \\
\hline Period 1 & $\begin{array}{l}-1.042 \\
(-5.15)\end{array}$ & $\begin{array}{l}-1.619 \\
(-7.20)\end{array}$ & $\begin{array}{c}.188 \\
(0.80)\end{array}$ & $\begin{array}{c}-0.54 \\
(-0.21)\end{array}$ & $\begin{array}{c}-.659 \\
(-3.09)\end{array}$ & $\begin{array}{c}-.905 \\
(-3.92)\end{array}$ \\
\hline Period 2 & $\begin{array}{c}-.490 \\
(-2.49)\end{array}$ & $\begin{array}{c}-.914 \\
(-4.34)\end{array}$ & $\begin{array}{c}-.191 \\
(-0.85)\end{array}$ & $\begin{array}{c}.202 \\
(-0.88)\end{array}$ & $\begin{array}{c}-354 \\
(-1.67)\end{array}$ & $\begin{array}{c}-.599 \\
(-2.71)\end{array}$ \\
\hline Period 3 & $\begin{array}{c}.635 \\
(-3.19)\end{array}$ & $\begin{array}{c}.836 \\
(-3.79)\end{array}$ & $\begin{array}{c}.019 \\
(0.08)\end{array}$ & $\begin{array}{c}-109 \\
(-0.45)\end{array}$ & $\begin{array}{c}-.419 \\
(-1.94)\end{array}$ & $\begin{array}{c}.542 \\
(-2.35)\end{array}$ \\
\hline Period 4 & $\begin{array}{c}-.679 \\
(-3.42) \\
\end{array}$ & $\begin{array}{c}-.729 \\
(-3.35)\end{array}$ & $\begin{array}{c}.031 \\
(0.13) \\
\end{array}$ & $\begin{array}{l}-.024 \\
(0.10) \\
\end{array}$ & $\begin{array}{c}-352 \\
(-1.64) \\
\end{array}$ & $\begin{array}{c}-.331 \\
(-1.45) \\
\end{array}$ \\
\hline Period 5 & $\begin{array}{c}-.070 \\
(-0.34)\end{array}$ & $\begin{array}{c}-.228 \\
(-1.04)\end{array}$ & $\begin{array}{c}.146 \\
(0.66)\end{array}$ & $\begin{array}{c}.089 \\
(0.40)\end{array}$ & $\begin{array}{l}-.124 \\
(0.59)\end{array}$ & $\begin{array}{c}-.030 \\
(-0.14)\end{array}$ \\
\hline Period 7 & $\begin{array}{c}.296 \\
(1.43)\end{array}$ & $\begin{array}{c}.051 \\
(0.23)\end{array}$ & $\begin{array}{c}-200 \\
(-0.91)\end{array}$ & $\begin{array}{c}-.279 \\
(-1.27)\end{array}$ & $\begin{array}{c}.052 \\
(0.25)\end{array}$ & $\begin{array}{c}-.226 \\
(-1.03)\end{array}$ \\
\hline Period 8 & $\begin{array}{c}.081 \\
(0.40)\end{array}$ & $\begin{array}{c}-.064 \\
(-0.29)\end{array}$ & $\begin{array}{c}-.254 \\
(-1.12)\end{array}$ & $\begin{array}{c}-.294 \\
(-1.27)\end{array}$ & $\begin{array}{c}-.066 \\
(-0.31) \\
\end{array}$ & \begin{tabular}{|c|}
-.265 \\
$(-1.18)$ \\
\end{tabular} \\
\hline Period 9 & $\begin{array}{c}.525 \\
(2.46)\end{array}$ & $\begin{array}{c}.408 \\
(1.79)\end{array}$ & $\begin{array}{c}-.473 \\
(-2.13)\end{array}$ & $\begin{array}{c}-.485 \\
(-2.14)\end{array}$ & $\begin{array}{c}-152 \\
(-0.72)\end{array}$ & $\begin{array}{c}-.322 \\
(-1.45)\end{array}$ \\
\hline Period 10 & $\begin{array}{c}.375 \\
(-1.85)\end{array}$ & $\begin{array}{c}.029 \\
(0.13)\end{array}$ & $\begin{array}{l}-1.052 \\
(-4.34)\end{array}$ & $\begin{array}{l}-1.093 \\
(-4.39)\end{array}$ & $\begin{array}{c}.927 \\
(-4.09)\end{array}$ & $\begin{array}{c}-.972 \\
(-4.01)\end{array}$ \\
\hline $\mathrm{N}$ & 640 & 572 & 640 & 576 & 640 & 576 \\
\hline$\overline{\mathrm{LL}}$ & -1072 & -789 & -998 & $\begin{array}{l}-962 \\
\end{array}$ & -1107 & -1010 \\
\hline
\end{tabular}

Z-statistics in parentheses. MW $=1$ for minimum-wage data and $\mathrm{MW}=0$ otherwise. Specifications marked by $(*)$ consider only data from wages greater than 4 .

Bold indicates significance at the $5 \%$ level, two-tailed test. 
Figure I

ESL Wages and Effort

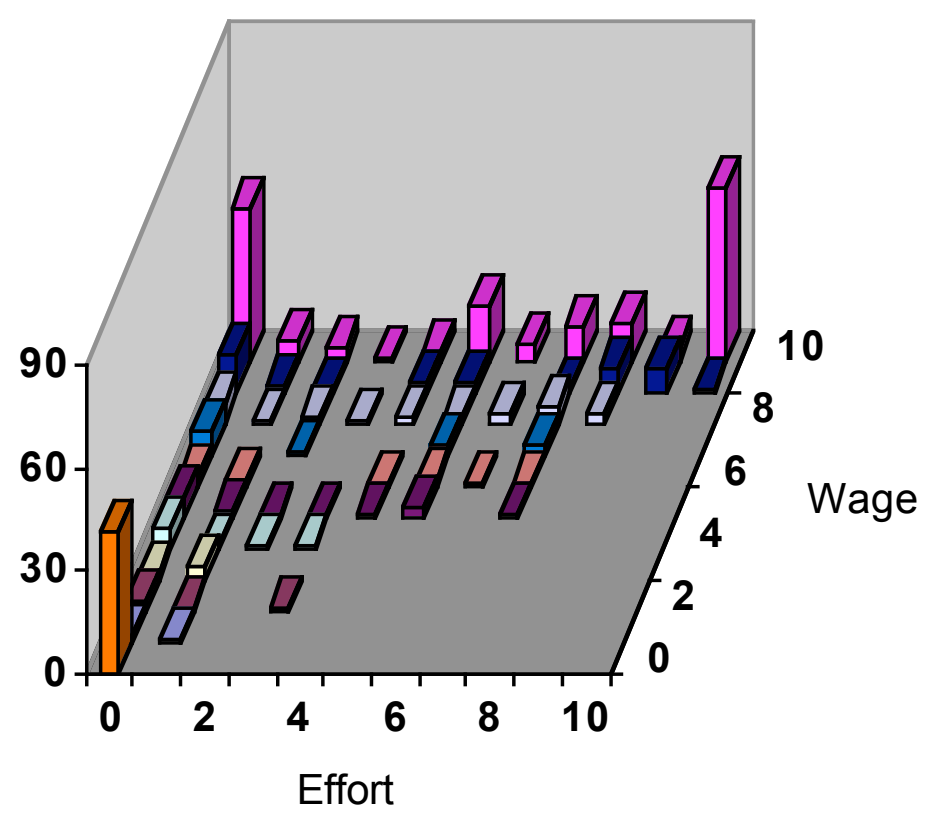


Figure II

ESF Wages and Effort

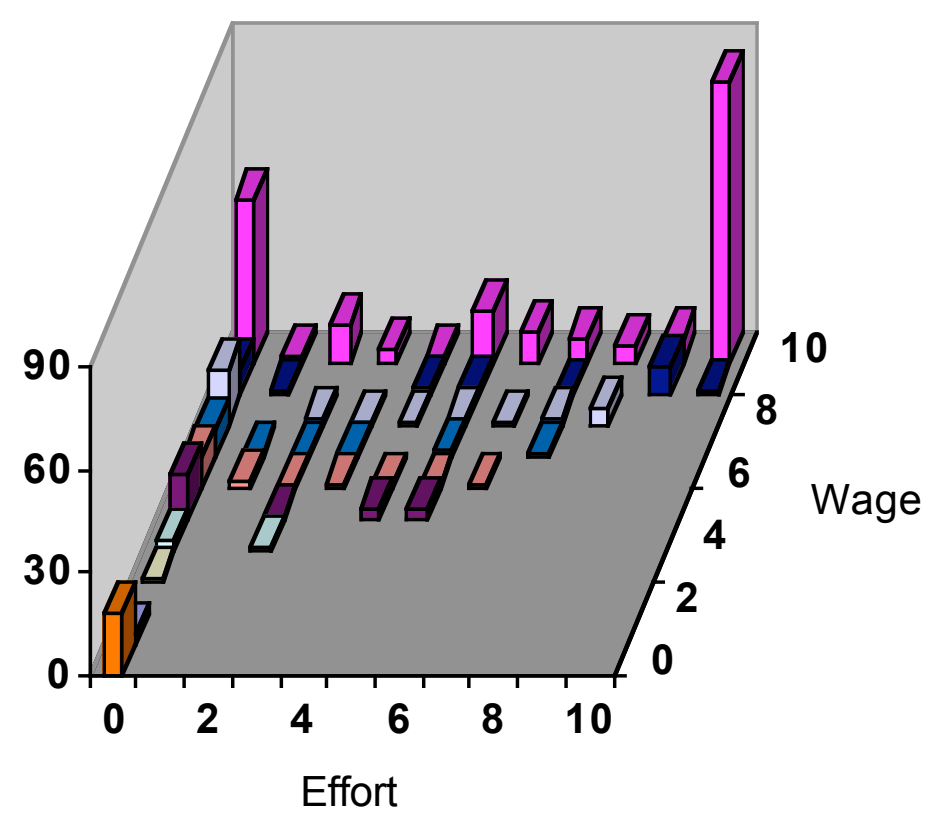


Figure III

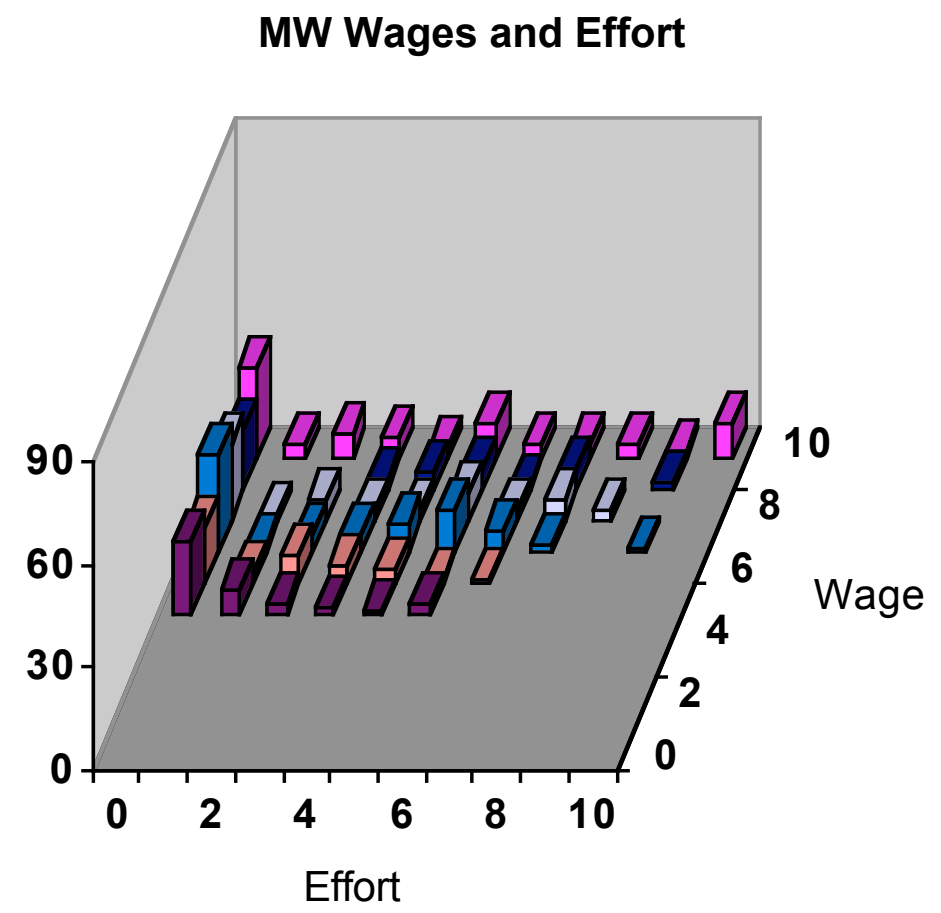


Figure IV: Average Wages over Time

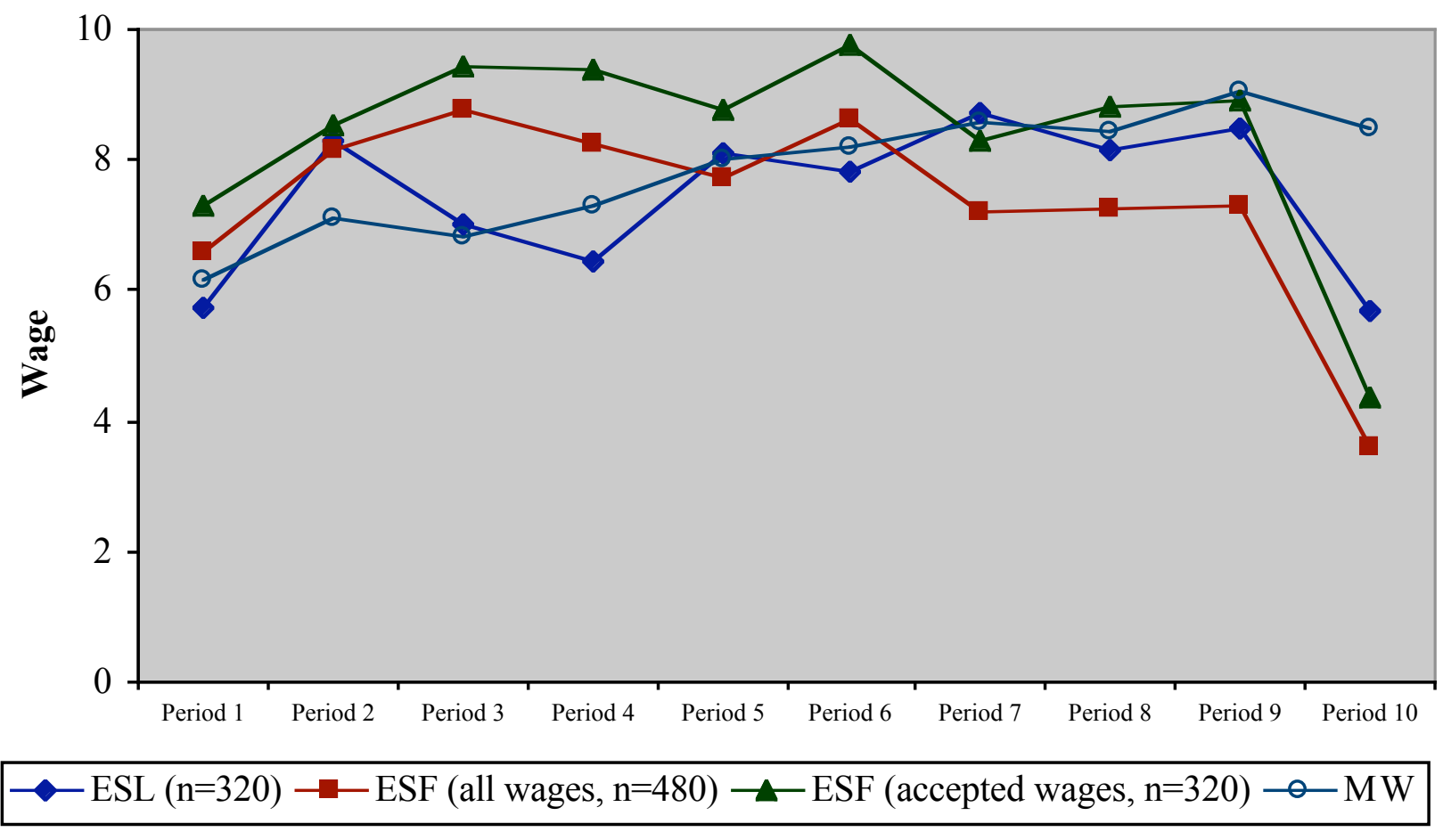


Figure V: Average Effort over Time

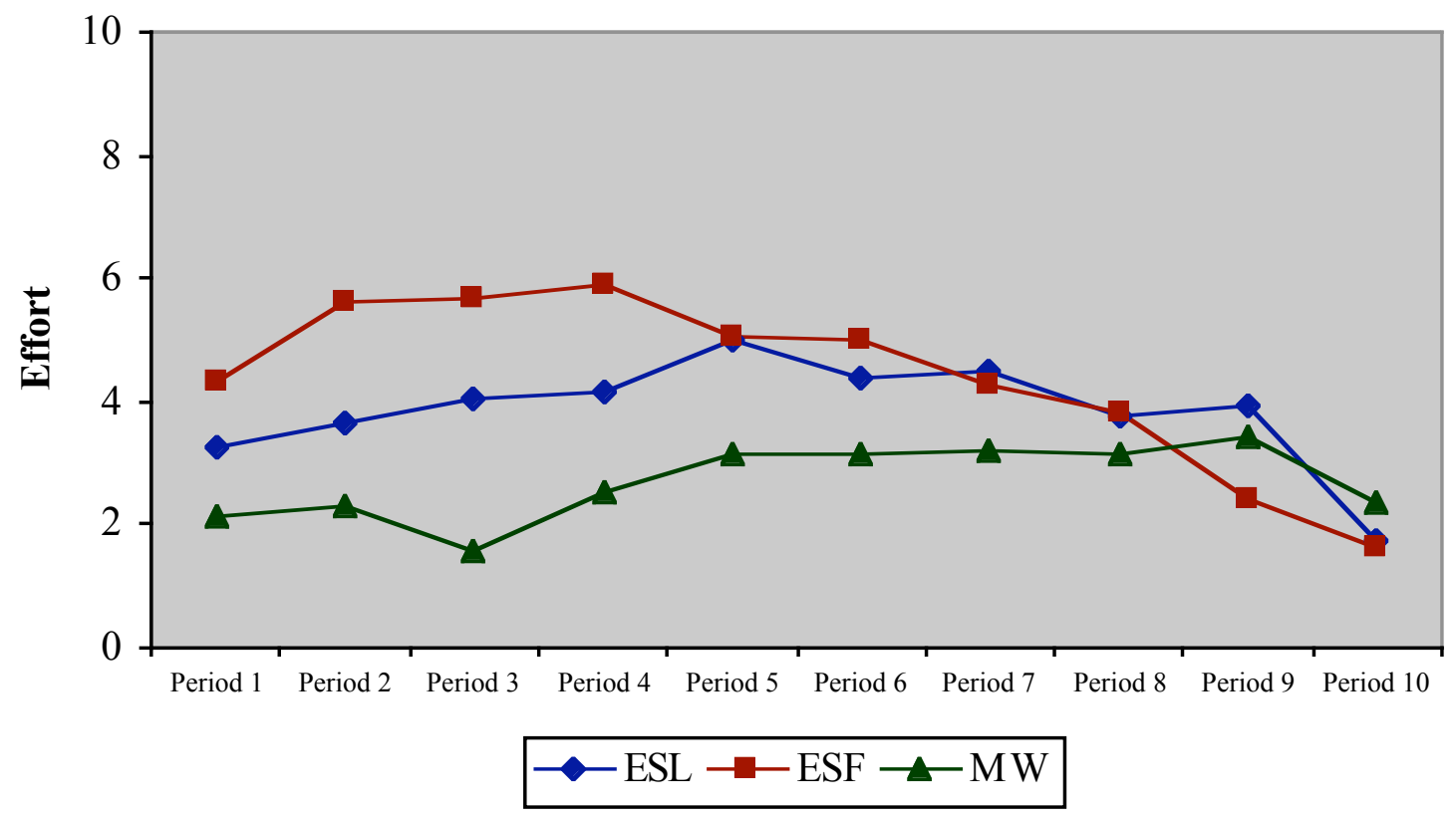

